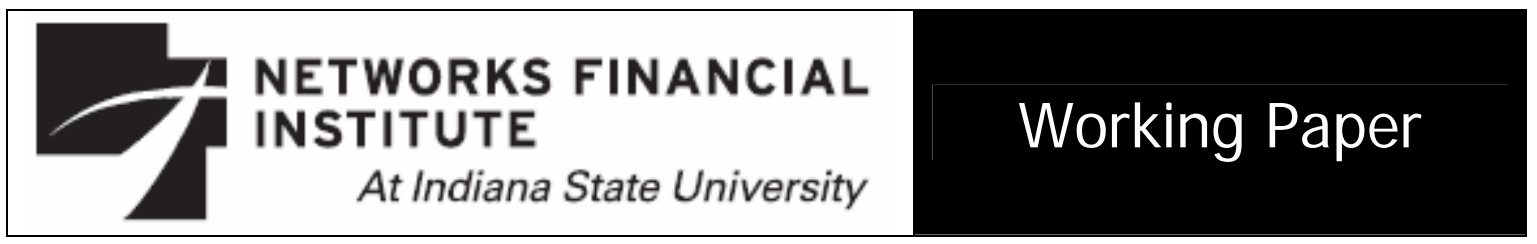

2007-WP-30

November 2007

\title{
Middle East and North Africa Markets: Investment Challenges and Market Structure
}

Tarek Zaher

Abstract: This paper highlights the major developments and structural changes in the Middle East and North Africa (MENA) markets. Noticeable growth was observed in these markets during the last decade. This is evidenced from the record growth rates in market capitalization, number of listed companies, value traded and shares traded in most of the MENA capital markets. Stock market boom was also observed, by the end of 2005, in many of the MENA countries. This was followed by a major correction (crash) in these MENA countries. To support the growth in capital markets and attract more local and foreign investors, MENA markets would need continue to incorporate changes to procedures, laws and the professional infrastructure within the financial market and better dissemination of information. Compliance with international and regional laws is also essential for a healthy development.

The paper also examines the evidence underlying the notion that there is increased integration of MENA and developed country financial markets and that MENA market equities do not represent a separate asset class. We analyze the correlation structures among individual country equity markets and efficient frontiers over two sub periods. We also analyze the structure of the correlations among political risk indicators for a similar group of countries over similar time periods. The results of the study suggest that capital market integration has accelerated in recent years, both economically and politically, but only for three countries in the MENA region. We therefore conclude that the MENA market countries should continue to be viewed as separate asset class from developed countries. These markets seem to be highly segmented and provide great diversification potentials to global investors.

About the Author: Tarek Zaher is a Professor of Finance, Analytical Department, Indiana State University College of Business. Dr. Zaher completed a Ph.D. from the University of Texas at Dallas. He has taught at Indiana State University since 1990. Prior to that, Dr. Zaher taught finance classes at the University of Texas at Arlington. Dr. Zaher has held a number of professional jobs with industry and provided consulting services to a number of companies in the United States and other foreign countries. Dr. Zaher also offered a number of seminars in investment and international finance at a number of institutions around the world. Dr. Zaher's research has been published in numerous scholarly journals. Dr. Zaher's primary research is in financial markets and institutions and investment with a special interest in emerging markets including the Middle Eastern and North African markets (MENA).

Keywords: MENA capital markets, foreign investment, financial markets.

The views expressed are those of the individual author and do not necessarily reflect official positions of Networks Financial Institute. Please address questions regarding content to Tarek Zaher at tzaher@isugw.indstate.edu. Any errors or omissions are the responsibility of the author. This research is made possible, in part, through the support of Networks Financial Institute, an Indiana State University initiative funded through the generosity of the Lilly Endowment. 


\section{Middle East and North Africa Markets: \\ Investment Challenges and Market Structure}

\section{Tarek Zaher}

\section{Major Developments and Structural Changes in MENA Capital Markets}

Traditionally, the boundaries of the Middle East consist of all countries in an area extending from the Atlantic Ocean in the West to the Persian Gulf in the East and bound by the Mediterranean, Europe and Asia in the North, and the Sahara in the South. Most MENA capital markets are considered as “emerging markets,” according to the World Bank.

The Middle East and North Africa (MENA) region continues to test the patience of both custodians and investors alike. Political instability, arcane market practices and thin trading volumes mean that many of the region's markets are of only marginal interest to global custodians and investors. The view of many of economist and investors is that the MENA markets region could develop to be among the most challenging markets in the world. Although progress can seem painfully slow, with many plans and little implementation, there are signs that the region's markets are making greater efforts to attract foreign investors.

Many of the Middle Eastern and North African (MENA) countries has witnessed significant economic and financial development, but MENA countries’ trade and capital flow remain marginal on a global level. Additionally, many countries in this region have suffered wars, political turmoil or economic instability, thus increasing the risk perception of investors and adding another major obstacle to increased access to MENA capital markets. However, the market's infrastructure is expected to continue to improve dramatically in some of these markets. Many of the MENA countries now realize the important multiple roles that equity markets can play in the economy and that these roles are more essential and critical in developing and high growth countries such as MENA 
economies. They also realize the need for a much stronger capital market and that more needs to be done to make these market prosper and to create a safer atmosphere for local and foreign investors. This is more important for countries that became partners in the free trade agreement with the United States of America and are members of the World Trade Organization (WTO). As more foreign and local companies set up their operations in the Middle East and North Africa, there will be an increase in demand for capital, so MENA markets would need the infrastructure to help that further development. This will include changes to procedures, laws and the professional infrastructure within the financial market, and better dissemination of information. In addition, MENA markets should have the ability to provide regional and international connectivity by complying with international and regional laws. This will make these markets more attractive to foreign investors.

In spite of the many obstacles to market growth, it seems that MENA capital markets have seen a noticeable growth over the 1995 to 2006 period. This is evidenced from the high growth rate in market capitalization, number of listed companies, value traded and shares traded, as reported in Table 1 . The percentage increase in the total market capitalization for MENA countries has ranged between $450 \%$ to $800 \%$, with the exception of Tunis which had a market capitalization growth of $9 \%$. Comparable high growth was also observed in the number of listed companies for most MENA countries. A very high growth was also recorded in the value traded and shares traded for the MENA countries. The value traded in 2006 ranged between 13 and 226 times the original values in 1995. The total shares traded also show high growth for some countries. The shares trade for the Saudi market, for example, has grown in 2006 to 465 times the levels 
they had in 1995, and the value traded for Egypt's market has grown by 115 times over the same period.

Among the major developments that also occurred in the MENA capital markets in the last decade is the stock market boom in many of the MENA countries. Towards the end of 2005, most stock markets in the region have seen heavy investments which have pushed the key indices to very high levels, thus suggesting a bubble in MENA markets to some observers. Almost all of the stock markets registered a noticeable improvement in their performance in the 2003-2005 period. Sedik and Petri (2006) report that the Arab Monetary Fund (AMF) composite index valued in U.S. dollars went up by 52 percent in 2004 and by about 91.6 percent in 2005. The individual countries’ AMF price indices reported in Table 1 indicate high performance for all the MENA countries reported in the table,. with the exception of Tunis, over the 2003-2005 periods. The AMF price index more than doubled in value for four MENA countries: Jordan (300\% increase), Saudi Arabia (434\% increase), Egypt (379\% increase), and Lebanon (294\% increase). Increases of 67\% for Kuwait, 61\% for Muscat, 35\% for Bahrain, and 20\% for Morocco were also observed.

One possible explanation for the improvement in MENA stock market performance is the increased liquidity and improved economic fundamentals in the region, due to high oil prices. This has contributed to the large accumulation of reserves by oil exporting countries and appears to have contributed significantly to asset price appreciation in the Middle East. Another possible explanation is the relative reluctance of rich Arab nationals to invest in overseas markets after the events of September 11, 2001; instead they invested in local markets. However, many of these markets have seen a 
major correction in the first half of 2006. The Saudi AMF price index dropped from a level of 878 in 2005 to a level of 404 in 2006, a loss of more than 50\% in value. The crash came after a four-year rally that started in 2002. A similar but less extensive crash occurred in the Jordanian market. The AMF price index for Jordan dropped from a level of 555 in 2005 to a level of 367 in 2006. The remaining MENA market AMF indices had little decrease, or showed an increase, over the same period. 
Table 1

Summary Market Characteristics for MENA Markets (1995-2006)

Source: Arab Monetary Fund, AMDB

Market Capitalization For MENA Markets

(Million \$)

\begin{tabular}{|c|c|c|c|c|c|c|c|c|c|c|c|c|}
\hline & 1995 & 1996 & 1997 & 1998 & 1999 & 2000 & 2001 & 2002 & 2003 & 2004 & 2005 & 2006 \\
\hline JORDAN & 4,724 & 4,556 & 5,456 & 5,863 & 5,835 & 4,943 & 6,314 & 7,087 & 10,963 & 18,383 & 37,639 & 29,729 \\
\hline BAHRAIN & 4,707 & 5,019 & 7,826 & 6,772 & 7,161 & 6,624 & 6,601 & 7,716 & 9,702 & 13,513 & 17,364 & 21,122 \\
\hline SAUDI ARABIA & 40,904 & 45,856 & 59,378 & 42,631 & 60,953 & 67,166 & 73,201 & 74,851 & 157,306 & 306,256 & 646,121 & 326,852 \\
\hline KUWAIT & 14,400 & 20,600 & 27,245 & 18,424 & 19,599 & 19,848 & 26,662 & 35,099 & 59,528 & 73,581 & 123,893 & 105,950 \\
\hline MOROCCO & 5,971 & 8,555 & 12,249 & 15,610 & 13,702 & 10,876 & 9,031 & 8,564 & 13,050 & 25,175 & 27,274 & 49,415 \\
\hline TUNIS & 3,869 & 3,852 & 2,316 & 2,229 & 2,638 & 2,809 & 2,230 & 2,126 & 2,440 & 2,574 & 2,821 & 4,222 \\
\hline MUSCAT & 1,971 & 2,753 & 7,313 & 4,537 & 4,303 & 3,518 & 2,634 & 5,268 & 7,246 & 9,318 & 12,062 & 13,037 \\
\hline LEBANON & - & 2,391 & 2,905 & 2,425 & 1,921 & 1,583 & 1,248 & 1,395 & 1,503 & 2,331 & 4,917 & 8,304 \\
\hline EGYPT & 8,074 & 14,185 & 20,876 & 24,381 & 33,039 & 30,791 & 24,309 & 26,339 & 27,847 & 38,077 & 79,508 & 93,496 \\
\hline
\end{tabular}

Number of Listed Companies

\begin{tabular}{|c|c|c|c|c|c|c|c|c|c|c|c|c|}
\hline & 1995 & 1996 & 1997 & 1998 & 1999 & 2000 & 2001 & 2002 & 2003 & 2004 & 2005 & 2006 \\
\hline JORDAN & 97 & 97 & 139 & 150 & 152 & 163 & 161 & 158 & 161 & 192 & 201 & 227 \\
\hline BAHRAIN & 36 & 37 & 40 & 42 & 41 & 41 & 42 & 40 & 44 & 45 & 47 & 50 \\
\hline SAUDI ARABIA & 69 & 70 & 71 & 74 & 72 & 75 & 76 & 68 & 70 & 73 & 77 & 86 \\
\hline KUWAIT & 51 & 60 & 74 & 78 & 85 & 86 & 88 & 95 & 108 & 125 & 156 & 180 \\
\hline MOROCCO & 44 & 48 & 49 & 53 & 54 & 54 & 55 & 55 & 52 & 53 & 54 & 63 \\
\hline TUNIS & 26 & 30 & 34 & 39 & 44 & 44 & 45 & 46 & 45 & 44 & 45 & 48 \\
\hline MUSCAT & 82 & 97 & 119 & 137 & 140 & 131 & 96 & 140 & 141 & 123 & 125 & 121 \\
\hline LEBANON & - & 6 & 8 & 12 & 13 & 13 & 14 & 13 & 14 & 16 & 15 & 16 \\
\hline EGYPT & 676 & 646 & 650 & 861 & 1,033 & 1,071 & 1,110 & 1,150 & 967 & 792 & 744 & 603 \\
\hline
\end{tabular}


Table 1 (Continued)

Value Traded
\begin{tabular}{|l|l|l|l|l|l|l|l|l|r|r|r|r|}
\hline & 1995 & 1996 & 1997 & 1998 & 1999 & 2000 & 2001 & 2002 & 2003 & 2004 & 2005 & 2006 \\
\hline JORDAN & 517 & 351 & 502 & 655 & 549 & 406 & 934 & 1,335 & 2,607 & 5,327 & 23,806 & 21,616 \\
\hline BAHRAIN & 106 & 177 & 472 & 577 & 444 & 245 & 250 & 206 & 261 & 463 & 711 & 1,387 \\
\hline SAUDI ARABIA & 6,194 & 6,767 & 16,547 & 13,745 & 15,087 & 17,313 & 22,223 & 30,974 & 159,056 & 472,991 & $1,103,583$ & $1,402,942$ \\
\hline KUWAIT & 6,394 & 19,224 & 34,579 & 10,918 & 6,001 & 4,208 & 11,711 & 22,123 & 54,729 & 51,818 & 97,290 & 59,600 \\
\hline MOROCCO & 291 & 545 & 1,067 & 1,402 & 2,525 & 1,211 & 841 & 1,440 & 2,443 & 3,757 & 7,859 & 9,110 \\
\hline TUNIS & 604 & 241 & 225 & 165 & 457 & 687 & 342 & 246 & 189 & 257 & 529 & 563 \\
\hline MUSCAT & 211 & 580 & 3,875 & 2,371 & 714 & 551 & 420 & 582 & 1,334 & 1,985 & 3,320 & 2,214 \\
\hline LEBANON & - & 67 & 610 & 337 & 91 & 118 & 53 & 115 & 131 & 198 & 923 & 2,032 \\
\hline EGYPT & 672 & 2,579 & 6,018 & 5,368 & 9,726 & 11,799 & 5,913 & 6,444 & 4,349 & 6,835 & 27,720 & 48,954 \\
\hline
\end{tabular}

\begin{tabular}{|c|c|c|c|c|c|c|c|c|c|c|c|c|}
\hline \multirow{2}{*}{ Shares Traded } & & & & & & & & & & & \multicolumn{2}{|c|}{ (Million ) } \\
\hline & 1995 & 1996 & 1997 & 1998 & 1999 & 2000 & 2001 & 2002 & 2003 & 2004 & 2005 & 2006 \\
\hline JORDAN & 125 & 162 & 191 & 249 & 264 & 178 & 335 & 456 & 1,000 & 1,322 & 2,583 & 4,268 \\
\hline BAHRAIN & 184 & 299 & 630 & 620 & 534 & 422 & 313 & 353 & 405 & 337 & 458 & 728 \\
\hline SAUDI ARABIA & 117 & 138 & 314 & 295 & 528 & 552 & 690 & 1,736 & 5,566 & 10,298 & 12,281 & 54,440 \\
\hline KUWAIT & 9,056 & 25,720 & 33,988 & 13,917 & 9,496 & 6,758 & 20,825 & 42,163 & 49,565 & 33,540 & 52,201 & 37,658 \\
\hline MOROCCO & 3 & 7 & 10 & 9 & 15 & 16 & 16 & 22 & 35 & 180 & 439 & 179 \\
\hline TUNIS & 18 & 11 & 11 & 11 & 27 & 29 & 21 & 17 & 13 & 21 & 41 & 56 \\
\hline MUSCAT & 41 & 114 & 374 & 284 & 138 & 144 & 124 & 191 & 294 & 350 & 452 & 922 \\
\hline LEBANON & - & 1 & 63 & 42 & 17 & 20 & 15 & 26 & 23 & 25 & 90 & 135 \\
\hline EGYPT & 46 & 170 & 275 & 411 & 846 & 953 & 1,184 & 833 & 1,368 & 2,435 & 5,310 & 9,013 \\
\hline
\end{tabular}


Table 1 (Continued)

AMF Price Indices

\begin{tabular}{|c|c|c|c|c|c|c|c|c|c|c|c|c|}
\hline & 1995 & 1996 & 1997 & 1998 & 1999 & 2000 & 2001 & 2002 & 2003 & 2004 & 2005 & 2006 \\
\hline JORDAN & 112 & 109 & 117 & 120 & 117 & 94 & 118 & 112 & 181 & 273 & 555 & 367 \\
\hline BAHRAIN & 91 & 96 & 137 & 123 & 122 & 109 & 97 & 111 & 135 & 160 & 183 & 187 \\
\hline SAUDI ARABIA & 100 & 113 & 136 & 91 & 119 & 128 & 130 & 133 & 202 & 411 & 878 & 404 \\
\hline KUWAIT & 118 & 147 & 157 & 97 & 95 & 102 & 134 & 158 & 259 & 287 & 435 & 403 \\
\hline MOROCCO & 109 & 144 & 182 & 226 & 207 & 156 & 129 & 128 & 198 & 221 & 239 & 405 \\
\hline TUNIS & 107 & 91 & 43 & 37 & 39 & 38 & 28 & 27 & 30 & 32 & 32 & 45 \\
\hline MUSCAT & 104 & 127 & 265 & 115 & 112 & 89 & 64 & 84 & 115 & 139 & 186 & 199 \\
\hline LEBANON & 100 & 81 & 98 & 78 & 61 & 49 & 34 & 36 & 37 & 53 & 109 & 103 \\
\hline EGYPT & 100 & 116 & 126 & 93 & 100 & 54 & 36 & 36 & 43 & 74 & 163 & 172 \\
\hline
\end{tabular}




\section{Empirical Research Objective}

When they make their portfolio allocation decisions, international investors have historically treated securities in emerging markets, including Middle Eastern and North African (MENA) markets, as a separate asset class. There is well documented evidence that emerging markets have high average stock returns and low correlations with developed markets and therefore they become an attractive choice for diversifying portfolios. DeSantis and Imrohorglu (1997) find that adding assets from emerging markets to a benchmark portfolio that contains U.S. assets creates a new portfolio with a considerable improvement in reward-to-risk performance. Harvey (1995a) suggests that adding equity investments from emerging markets to a portfolio of developed equity market shifts significantly the mean-variance efficient frontier to the left. However, recent developments in the economic, legal, accounting, and financial systems in the MENA region may erode the sources of separation between MENA markets and developing markets and increase the integration between the two markets. Henry [2000] and Bekaert, Harvey, and Lumsdaine (2002) find a whole spectrum of financial liberalization developments that have eased the flow of capital into and out of emerging markets. Included in these liberalizations are capital market reforms that have reduced the constraints and limits on foreign investors’ holdings in local firms' equities and the establishment of country funds.

In this paper, we examine the evidence underlying the notion that there is increased integration of MENA and developed country financial markets and that MENA market equities do not represent a separate asset class. We analyze the correlation structures among individual country equity markets during the 1995-2004 period. In particular, we compare 
the individual country (MSCI) stock return correlation structures and efficient frontiers over the 1995 to 1999 period and the 2000 to 2004 period. We also analyze the structure of the correlations among political risk indicators for a similar group of countries over similar time periods.

\section{Data and Quantitative Evidence}

\section{A. Data}

This section compares the empirical characteristics of the MENA markets with those of selected developed markets. The return series were obtained from a DataStream data set and consist of monthly stock return series over the ten year period January 1, 1995 to December 31, 2004. We use monthly returns to avoid biases that could result from nontrading days and non-synchronous trading hours and days. There are several possible sources for MENA market returns: MSCI, IFC and local index. Each of these sources began coverage of MENA markets at different dates. In this study, we chose the provider that started coverage earliest. For instance, Jordan and Turkey were covered by MSCI in the late '80s. Egypt, Israel, and Morocco are also covered by MSCI during the ‘90s. Saudi Arabia, Bahrain and Oman are only covered by IFC. Kuwait, Lebanon and Tunisia price series are only available in local indices and, their coverage started in the '90s. The price series for developed markets are available since the '60s or '70s through MSCI. We chose a starting date of January 1, 1995 because nine of the eleven MENA return series are only available after 1990. The observation periods for all countries are not the same, but the construction of the indices is based on value-weighted portfolios. MSCI and IFC indices are usually highly correlated and reflect a constant methodology across markets; they capture the spirit of an all-share index by including replicable subsets of shares and targeting sixty percent of 
total market capitalization. These indices do not take into consideration restrictions on foreign ownership.

The equity returns presented are calculated in U.S. dollars. This is more appropriate in segmented markets because inflation trends are taken into account through a Fisher equation (Liew 1995). Also, it provides uniformity in the comparison of one market to another. When we use local series (Kuwait, Lebanon and Tunisia), prices are converted in U.S. dollars using the exchange rate series provided by DataStream.

\section{B. Risk and Returns Evidence}

Table 2 show the monthly returns and risks (standard deviations) for ten MENA countries over the period of study (1995-2004) and the two sub periods (1995:1-1999:12 and 2000:1-2004:12). For comparison purposes we also show the returns and risks on three international MSCI indexes: the Emerging Market (EM), the World Index and the Middle East Index (ME). We also include monthly equity returns and risks for three developed markets, Japan, the U.K. and the U.S.A. We compute monthly returns as the natural logarithmic difference of the monthly prices times 100 , that is $100 * \mathrm{Lon}(\mathrm{Pt} / \mathrm{Pt}-1)$. The summary statistics of the monthly stock index returns are presented in U.S. dollar terms. The results show little evidence of risk-return hypothesis (that is, high risks imply high returns) in selected MENA stock markets. Second, the pattern of higher emerging market returns (means) and high risks (standard deviations) compared to the developed countries that has been documented in a number of studies including DeSantis and Imrohorglu (1997), Harvey (1995a) and Saunders and Walter (2002) is partially supported in this study. The mean of monthly return during the ten year period (1995-2004) were relatively lower than the selected developed countries and the world index return for most of the MENA countries. 
Very high return was recorded only for Saudi Arabia (1.33\%) and Turkey (0.85\%). The returns for Morocco (0.64\%), Oman (0.69\%), Bahrain (.54\%), Israel (0.57\%) and Jordan (0.52\%) are lower than the U.K. (0.76\%) and U.S.A. (0.80\%) returns but higher than Japan $(0.45 \%)$ and the World return (0.46\%). The monthly risk adjusted return (Sharp Measure: Mean Return/Std Dev.) was also relatively high for the same countries. Saudi Arabia has the highest adjusted return (0.28\%).

Table 2

SUMMARY STATISTICS: Descriptive Statistics for each Monthly Return Series

PANEL A: 1995.12 to 2004:12

\begin{tabular}{|c|c|c|c|c|c|c|c|}
\hline Bahrain & $\begin{array}{c}\text { Obs. } \\
70\end{array}$ & $\begin{array}{l}\text { Mean } \\
0.54 \%\end{array}$ & $\begin{array}{c}\text { Std. Dev. } \\
3.82 \%\end{array}$ & $\begin{array}{c}\text { Mean/Std } \\
\text { Dev. } \\
14.136 \%\end{array}$ & $\begin{array}{c}\text { Skewness } \\
0.045\end{array}$ & $\begin{array}{c}\text { Kurtosis } \\
4.873\end{array}$ & $\begin{array}{c}\text { JB } \\
10.258\end{array}$ \\
\hline Egypt & 106 & $0.11 \%$ & $7.46 \%$ & $1.475 \%$ & 0.506 & 2.900 & 4.571 \\
\hline Israel & 94 & $0.57 \%$ & $7.51 \%$ & $7.590 \%$ & -0.643 & 3.118 & 6.538 \\
\hline Jordan & 238 & $0.52 \%$ & $4.41 \%$ & $11.791 \%$ & 0.266 & 3.897 & 10.786 \\
\hline Lebanon & 70 & $-0.50 \%$ & $8.11 \%$ & $-6.165 \%$ & 0.319 & 3.543 & 2.046 \\
\hline Morocco & 106 & $0.64 \%$ & $4.94 \%$ & $12.955 \%$ & -0.225 & 3.448 & 1.782 \\
\hline Oman & 70 & $0.69 \%$ & $5.75 \%$ & $12.000 \%$ & 0.588 & 3.797 & 5.890 \\
\hline \multicolumn{8}{|l|}{ Saudi } \\
\hline Arabia & 82 & $1.33 \%$ & $4.73 \%$ & $28.118 \%$ & -0.440 & 3.185 & 2.760 \\
\hline Turkey & 214 & $0.85 \%$ & $18.43 \%$ & $4.612 \%$ & 0.134 & 3.455 & 2.491 \\
\hline Tunisia & 106 & $-0.74 \%$ & $5.28 \%$ & $-14.015 \%$ & 0.028 & 6.214 & 45.626 \\
\hline ME Index & 106 & $0.29 \%$ & $5.85 \%$ & $4.957 \%$ & -1.419 & 7.115 & 110.340 \\
\hline EM Index & 238 & $0.60 \%$ & $6.59 \%$ & $9.105 \%$ & -0.946 & 5.881 & 117.826 \\
\hline Japan & 237 & $0.45 \%$ & $6.95 \%$ & $6.475 \%$ & 0.094 & 3.248 & 0.956 \\
\hline U.K. & 237 & $0.76 \%$ & $5.24 \%$ & $14.504 \%$ & -0.341 & 4.652 & 31.553 \\
\hline U.S.A. & 237 & $0.80 \%$ & $4.54 \%$ & $17.621 \%$ & -1.053 & 6.637 & 174.434 \\
\hline World & 201 & $0.46 \%$ & $4.21 \%$ & $10.926 \%$ & -0.553 & 3.777 & 15.300 \\
\hline
\end{tabular}


Table 2 (continued)

PANEL B: 1995:1 to 1999:12

\begin{tabular}{|c|c|c|c|c|c|c|c|}
\hline & Obs & Mean & Std. Dev. & $\begin{array}{l}\text { Mean/Std } \\
\text { Dev }\end{array}$ & Skewness & Kurtosis & JB \\
\hline Bahrain & 12 & $0.28 \%$ & $1.60 \%$ & $17.500 \%$ & -0.82 & 4.85 & 3.056 \\
\hline Egypt & 48 & $0.60 \%$ & $7.63 \%$ & $7.864 \%$ & 0.92 & 3.48 & 7.177 \\
\hline Israel & 36 & $1.30 \%$ & $6.82 \%$ & $19.062 \%$ & -0.26 & 2.23 & 1.295 \\
\hline Jordan & 60 & $0.33 \%$ & $3.51 \%$ & $9.402 \%$ & 0.43 & 2.76 & 2.010 \\
\hline Lebanon & 12 & $-1.65 \%$ & $11.73 \%$ & $-14.066 \%$ & 0.42 & 2.81 & 0.377 \\
\hline Morocco & 48 & $1.62 \%$ & $4.67 \%$ & $34.690 \%$ & 0.09 & 3.48 & 0.521 \\
\hline Oman & 12 & $0.58 \%$ & $9.72 \%$ & $5.967 \%$ & 0.48 & 1.97 & 0.991 \\
\hline Saudi Arabia & 24 & $0.17 \%$ & $5.44 \%$ & $3.125 \%$ & 0.07 & 2.25 & 0.582 \\
\hline Turkey & 60 & $2.44 \%$ & $16.93 \%$ & $14.412 \%$ & 0.25 & 4.98 & 10.422 \\
\hline Tunisia & 48 & $-1.36 \%$ & $6.45 \%$ & $-21.085 \%$ & -0.01 & 5.30 & 10.545 \\
\hline ME Index & 48 & $-0.41 \%$ & $7.08 \%$ & $-5.791 \%$ & -1.32 & 6.16 & 33.881 \\
\hline EM Index & 60 & $-0.11 \%$ & $7.04 \%$ & $-1.563 \%$ & -1.38 & 7.02 & 59.528 \\
\hline Japan & 60 & $0.11 \%$ & $6.25 \%$ & $1.760 \%$ & 0.20 & 2.38 & 1.358 \\
\hline U.K. & 60 & $1.29 \%$ & $3.16 \%$ & $40.823 \%$ & -0.34 & 3.17 & 1.201 \\
\hline U.S.A. & 60 & $2.02 \%$ & $4.07 \%$ & $49.631 \%$ & -1.44 & 6.58 & 52.913 \\
\hline World & 60 & $1.31 \%$ & $3.86 \%$ & $33.938 \%$ & -1.43 & 7.33 & 67.441 \\
\hline
\end{tabular}

Summary Statistics: Descriptive Statistics for each Monthly Return Series

PANEL C: 2000:1 to 2004:12

\begin{tabular}{|c|c|c|c|c|c|c|c|}
\hline & Obs. & Mean & Std. Dev. & Mean/Std Dev & Skewness & Kurtosis & JB \\
\hline Bahrain & 60 & $0.59 \%$ & $4.14 \%$ & $14.251 \%$ & 0.02 & 4.26 & 3.831 \\
\hline Egypt & 60 & $-0.30 \%$ & $7.35 \%$ & $-4.082 \%$ & 0.12 & 2.13 & 1.958 \\
\hline Israel & 60 & $0.12 \%$ & $7.93 \%$ & $1.513 \%$ & -0.75 & 3.20 & 5.506 \\
\hline Jordan & 60 & $1.24 \%$ & $4.27 \%$ & $29.040 \%$ & 0.41 & 2.42 & 2.424 \\
\hline Lebanon & 60 & $-0.26 \%$ & $7.26 \%$ & $-3.581 \%$ & 0.35 & 3.32 & 1.431 \\
\hline Morocco & 60 & $-0.17 \%$ & $5.05 \%$ & $-3.366 \%$ & -0.38 & 3.16 & 1.450 \\
\hline Oman & 60 & $0.72 \%$ & $4.67 \%$ & $15.418 \%$ & 0.58 & 4.03 & 5.757 \\
\hline Saudi Arabia & 60 & $1.80 \%$ & $4.36 \%$ & $41.284 \%$ & -0.68 & 4.15 & 7.644 \\
\hline Turkey & 60 & $-1.07 \%$ & $18.17 \%$ & $-5.889 \%$ & -0.45 & 3.18 & 2.052 \\
\hline Tunisia & 60 & $-0.24 \%$ & $4.04 \%$ & $-5.941 \%$ & 0.74 & 4.42 & 10.096 \\
\hline ME Index & 60 & $0.88 \%$ & $4.58 \%$ & $19.214 \%$ & -0.92 & 3.86 & 10.044 \\
\hline EM Index & 60 & $0.06 \%$ & $5.64 \%$ & $1.064 \%$ & -0.51 & 2.88 & 2.544 \\
\hline Japan & 60 & $-0.87 \%$ & $5.65 \%$ & $-15.398 \%$ & 0.29 & 2.13 & 2.602 \\
\hline U.K. & 60 & $-0.43 \%$ & $4.47 \%$ & $-9.620 \%$ & -0.02 & 2.79 & 0.114 \\
\hline U.S.A. & 60 & $-0.57 \%$ & $4.84 \%$ & $-11.777 \%$ & -0.10 & 2.65 & 0.380 \\
\hline World & 60 & $-0.52 \%$ & $4.58 \%$ & $-11.354 \%$ & -0.27 & 2.60 & 1.046 \\
\hline
\end{tabular}


Relative high return was observed only for three of the MENA countries (Saudi Arabia, Morocco, and Israel) during the 1995-1999 sub periods. However, there was a major increase in the risk level (standard deviation) for most of the MENA countries during this sub period. As a result, the risk-adjusted return for all of the MENA countries (except Saudi Arabia) dropped below the risk-adjusted return for the U.K., the U.S.A., and the world. Most of the MENA countries, however, outperformed the emerging market index-adjusted return (which turned negative), and some MENA countries also outperformed Japan.

During the second sub period (2000-2004), a major shift in the relative performance of developed countries and MENA countries occurred. The high positive return and riskadjusted return for the developed countries and the world changed to a high negative return. Five of the ten MENA countries continued to have high positive return and risk-adjusted return. The tragedy of September 11 may have had a distorting impact on the returns and risks of developed countries in the period immediately surrounding the tragedy.

When making their asset allocation decisions, international portfolios investors and portfolio managers consider individual returns and risks as important ingredients for their decision-making process. However, correlations among country returns are also essential and important factors that will influence the investors' decision. For example, if correlations between MENA markets and developed market countries in the study have risen with time, this would support the view that these countries' equity markets are converging toward a single asset class, thus indicating a greater integration of world capital markets. Therefore investors or portfolio fund managers are less able to achieve gross diversification gains by allocating some of their assets to investment in MENA markets. 
We examine the monthly return correlation relationships using U.S. dollar-adjusted returns. To test the degree to which correlations among MENA and developed countries have changed, we compute correlations for each of the two equal sub periods in the study (1995-1999 and 2000-2004) separately. Table 3 shows the correlations among developed and MENA countries in each of the two sub periods analyzed, as well as correlation-bycorrelation tests as to whether MENA market-developed country correlations increased over the later sub period (2000-2004) compared to the 1995-1999 sub period.

\section{Table 3}

\section{CORRELATIONS IN RETURNS}

Panel A: 1995-1999

\begin{tabular}{|c|c|c|c|c|c|c|c|c|c|c|}
\hline & Bahrain & Egypt & Israel & Jordan & Lebanon & Morocco & Oman & Saudi Arabia & Turkey & Tunisia \\
\hline Bahrain & 1.00 & & & & & & & & & \\
\hline Egypt & 0.25 & 1.00 & & & & & & & & \\
\hline Israel & -0.08 & 0.17 & 1.00 & & & & & & & \\
\hline Jordan & -0.06 & 0.60 & 0.39 & 1.00 & & & & & & \\
\hline Lebanon & -0.34 & 0.32 & 0.28 & -0.06 & 1.00 & & & & & \\
\hline Morocco & 0.27 & 0.22 & -0.65 & -0.02 & -0.09 & 1.00 & & & & \\
\hline Oman & 0.45 & 0.14 & -0.51 & -0.25 & -0.18 & 0.66 & 1.00 & & & \\
\hline Saudi Arabia & 0.43 & 0.13 & 0.05 & -0.10 & 0.07 & 0.11 & 0.06 & 1.00 & & \\
\hline Turkey & 0.24 & 0.31 & 0.56 & 0.50 & -0.13 & -0.34 & -0.11 & -0.09 & 1.00 & \\
\hline Tunisia & -0.20 & -0.03 & -0.41 & 0.27 & -0.27 & 0.11 & -0.28 & -0.56 & 0.02 & 1.00 \\
\hline ME Index & 0.77 & 0.34 & 0.45 & 0.18 & 0.02 & 0.10 & 0.15 & 0.56 & 0.36 & -0.50 \\
\hline EM Index & 0.47 & -0.05 & 0.55 & 0.02 & 0.19 & -0.22 & -0.06 & 0.45 & 0.23 & -0.54 \\
\hline Japan & 0.51 & -0.03 & 0.24 & -0.12 & -0.25 & 0.07 & 0.15 & 0.68 & 0.25 & -0.61 \\
\hline U.K. & 0.72 & 0.23 & 0.29 & 0.36 & -0.30 & -0.10 & 0.01 & 0.37 & 0.65 & -0.08 \\
\hline U.S.A. & 0.57 & 0.44 & 0.35 & 0.20 & 0.27 & 0.11 & 0.04 & 0.38 & 0.06 & -0.40 \\
\hline World & 0.68 & 0.42 & 0.39 & 0.18 & 0.19 & 0.09 & 0.10 & 0.56 & 0.28 & -0.49 \\
\hline
\end{tabular}


Table 3 (continued)

Panel B: 2000-2004

\begin{tabular}{|c|c|c|c|c|c|c|c|c|c|c|}
\hline & Bahrain & Egypt & Israel & Jordan & Lebanon & Morocco & Oman & Saudi Arabia & Turkey & Tunisia \\
\hline Bahrain & 1.00 & & & & & & & & & \\
\hline Egypt & 0.47 & 1.00 & & & & & & & & \\
\hline Israel & 0.19 & 0.09 & 1.00 & & & & & & & \\
\hline Jordan & 0.33 & 0.31 & 0.10 & 1.00 & & & & & & \\
\hline Lebanon & 0.10 & 0.31 & 0.09 & 0.05 & 1.00 & & & & & \\
\hline Morocco & 0.16 & 0.31 & 0.26 & 0.23 & 0.30 & 1.00 & & & & \\
\hline Oman & 0.34 & 0.33 & 0.21 & 0.22 & 0.00 & 0.20 & 1.00 & & & \\
\hline Saudi Arabia & 0.21 & 0.28 & 0.15 & 0.23 & 0.27 & 0.16 & 0.17 & 1.00 & & \\
\hline Turkey & 0.40 & 0.21 & 0.21 & 0.13 & 0.16 & 0.01 & -0.18 & 0.18 & 1.00 & \\
\hline Tunisia & 0.31 & 0.33 & 0.21 & 0.17 & -0.06 & 0.17 & 0.31 & 0.12 & 0.08 & 1.00 \\
\hline ME Index & 0.39 & 0.39 & 0.49 & 0.17 & 0.26 & 0.46 & 0.17 & 0.49 & 0.36 & 0.25 \\
\hline Emerging Index & 0.50 & 0.41 & 0.33 & 0.30 & 0.19 & 0.31 & 0.04 & 0.35 & 0.64 & 0.18 \\
\hline Japan & 0.30 & 0.38 & 0.19 & 0.09 & 0.20 & 0.36 & 0.22 & 0.34 & 0.30 & 0.04 \\
\hline U.K. & 0.35 & 0.19 & 0.31 & 0.17 & 0.25 & 0.29 & 0.08 & 0.27 & 0.56 & 0.15 \\
\hline U.S.A. & 0.30 & 0.18 & 0.41 & 0.16 & 0.28 & 0.17 & -0.01 & 0.23 & 0.63 & 0.01 \\
\hline World & 0.38 & 0.26 & 0.45 & 0.20 & 0.26 & 0.26 & 0.05 & 0.29 & 0.65 & 0.09 \\
\hline
\end{tabular}

\section{Panel C: Tests for significance in correlation difference in the two sub periods}

$\begin{array}{ccccccccccc}\text { Z test } & \text { Bahrain } & \text { Egypt } & \text { Israel } & \text { Jordan } & \text { Lebanon } & \text { Morocco } & \text { Oman } & \text { Saudi Arabia } & \text { Turkey } & \text { Tunisia } \\ \text { Middle East Index } & -1.06 & 0.22 & 0.20 & -0.04 & 0.67 & \mathbf{1 . 7 8} & 0.06 & -0.27 & 0.03 & \mathbf{3 . 7 6} \\ \text { Emerging Index } & 0.08 & \mathbf{2 . 3 5} & -1.02 & \mathbf{1 . 5 0} & -0.02 & \mathbf{2 . 6 5} & 0.29 & -0.39 & \mathbf{2 . 2 1} & \mathbf{3 . 5 9} \\ \text { Japan } & -0.58 & \mathbf{2 . 0 4} & -0.25 & 1.15 & 1.27 & \mathbf{1 . 4 5} & 0.18 & \mathbf{- 1 . 3 4} & 0.26 & \mathbf{3 . 2 4} \\ \text { U.K. } & -1.02 & -0.25 & 0.11 & -1.01 & \mathbf{1 . 5 3} & \mathbf{1 . 9 4} & 0.19 & -0.39 & -0.47 & 1.15 \\ \text { U.S.A. } & -0.74 & -1.33 & 0.29 & -0.25 & 0.03 & 0.35 & -0.15 & -0.59 & \mathbf{3 . 0 7} & \mathbf{2 . 0 4} \\ \text { World } & -0.85 & -0.80 & 0.31 & 0.11 & 0.18 & 0.89 & -0.13 & -1.03 & \mathbf{1 . 9 5} & \mathbf{2 . 9 1}\end{array}$

Table 3 shows that the MENA market-developed country correlations did not increase from the first to the second sub period for most MENA countries. The same can be said about the MENA market-World correlations. However a major increase in the correlation was observed for Tunisia and Morocco and to a lesser extent for Turkey. The Z-ratio test as to whether a correlation increased to a statistically significant degree is significant at the $10 \%$ confidence level (or above) in only three cases. Tunisia is showing a statistically significant increase in the correlation with Japan, the U.S.A. and the world, but not with the U.K.. Morocco is showing significant increase in correlation with Japan 
and the U.K. only, while Turkey is having an increase in correlation with the U.S.A. and the world only.

To test for the effects of the increased correlations (integration) on the potential gains from simple country-by-country diversification, we compare the efficient meanvariance of returns frontier, based on monthly country index returns, for the 1995-1999 period with the efficient frontier for the 2000-2004 period. Exhibit 1 shows the efficient frontier for both sub periods. It is clear that there are some gains from simple country-bycountry diversification in the (2000-2004) sub period overall risk-return ranges. The slightly more convex frontier in the second sub period reflects the low positive or lack of correlation among country returns shown in Table 3. These findings indicate that simple asset allocations in some MENA countries will enhance the performance for investors or portfolio managers in some developed countries. In developing their strategies, managers need to be selective in including some of the MENA market countries in their investment plans, since only few of these countries show increased correlation over time with the developed countries. Attention should also be given to industry as well as firm analysis in these countries. 
Exhibit 1

EFFICIENT FRONTIER

SUB PERIOD COMPARISON

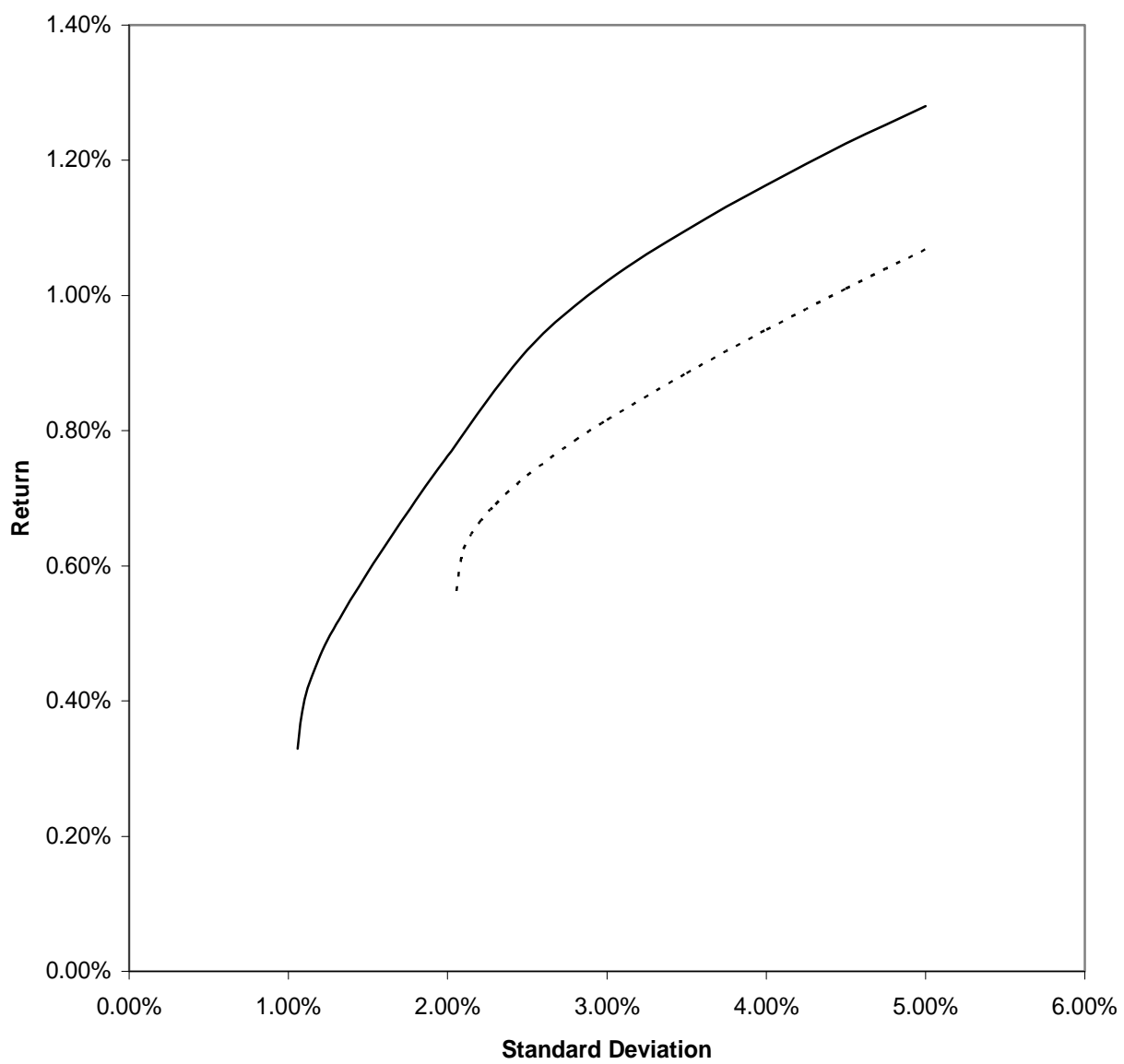

Efficient Frontier [1995-1999]

... . . Efficient Frontier [2000-2004]

Mei (1999), among others, has found that political events have had significant

impact on some capital markets around the world. We therefore test whether political factors have had an impact on return correlations. We use changes in Political Risk

Service's monthly index of political risk to analyze political trends among MENA and developed market countries. According to the International Country Risk Guide (ICRG) political risk assessment, countries are rated on a scale of 1 to 100 (a high rating means less risky and a low rating means more risky). As is evident in Table 4, little more than 
half of political risk correlations are positive and the remaining correlations are negative in both sub periods. Further tests of significant differences in correlation of political risk between the two sub periods reveals that there is significant difference in correlations for six of the ten MENA countries with developed countries. But, for two of the six countries, the correlation is negative. These countries include Tunisia, Morocco, Lebanon, Jordan and Egypt. It is possible that changes in legal and accounting systems, as well as changes in economic policies and regulations, have had an impact on the increased integration in some of these countries.

\section{Table 4}

\section{POLITICAL RISK}

\section{Panel A: Correlations of Political Risk}

\begin{tabular}{|c|c|c|c|c|c|c|c|c|c|c|}
\hline $\begin{array}{c}\text { 1995-1999 } \\
\text { Bahrain }\end{array}$ & Bahrain & Egypt & Israel & Jordan & Lebanon & Morocco & Oman & Saudi Arabia & Turkey & Tunisia \\
\hline Egypt & 0.23 & 1 & & & & & & & & \\
\hline Israel & 0.69 & -0.05 & 1 & & & & & & & \\
\hline Jordan & 0.57 & 0.40 & 0.50 & 1 & & & & & & \\
\hline Lebanon & 0.83 & 0.30 & 0.60 & 0.46 & 1 & & & & & \\
\hline Morocco & -0.09 & 0.67 & -0.33 & 0.15 & 0.07 & 1 & & & & \\
\hline Oman & -0.64 & 0.47 & -0.76 & -0.36 & -0.46 & 0.63 & 1 & & & \\
\hline Saudi Arabia & 0.09 & 0.05 & 0.25 & 0.24 & 0.26 & 0.12 & -0.16 & 1 & & \\
\hline Turkey & 0.61 & -0.22 & 0.60 & 0.30 & 0.69 & -0.39 & -0.71 & 0.18 & 1 & \\
\hline Tunisia & -0.65 & 0.40 & -0.54 & -0.09 & -0.52 & 0.57 & 0.78 & 0.13 & -0.68 & 1 \\
\hline Japan & -0.10 & -0.55 & 0.07 & -0.28 & 0.14 & -0.35 & -0.30 & 0.45 & 0.34 & -0.24 \\
\hline U.K. & -0.73 & 0.25 & -0.69 & -0.39 & -0.53 & 0.55 & 0.85 & 0.09 & -0.73 & 0.83 \\
\hline U.S. & -0.71 & 0.06 & -0.81 & -0.65 & -0.54 & 0.31 & 0.80 & -0.37 & -0.54 & 0.48 \\
\hline 2000-2004 & Bahrain & Egypt & Israel & Jordan & Lebanon & Morocco & Oman & Saudi Arabia & Turkey & Tunisia \\
\hline Bahrain & 1 & & & & & & & & & \\
\hline Egypt & -0.56 & 1 & & & & & & & & \\
\hline Israel & 0.47 & -0.08 & 1 & & & & & & & \\
\hline Jordan & -0.04 & 0.65 & 0.35 & 1 & & & & & & \\
\hline Lebanon & -0.36 & 0.60 & -0.16 & 0.53 & 1 & & & & & \\
\hline Morocco & 0.67 & -0.21 & 0.83 & 0.31 & -0.30 & 1 & & & & \\
\hline Oman & -0.35 & 0.60 & 0.08 & 0.45 & 0.46 & 0.09 & 1 & & & \\
\hline Saudi Arabia & 0.37 & 0.15 & 0.08 & 0.43 & 0.51 & 0.07 & 0.19 & 1 & & \\
\hline Turkey & 0.21 & -0.11 & 0.56 & 0.30 & -0.03 & 0.52 & -0.02 & -0.16 & 1 & \\
\hline Tunisia & -0.87 & 0.72 & -0.19 & 0.34 & 0.48 & -0.32 & 0.61 & -0.25 & -0.02 & 1 \\
\hline Japan & 0.81 & -0.25 & 0.31 & 0.14 & 0.03 & 0.44 & -0.16 & 0.65 & -0.04 & -0.65 \\
\hline U.K. & -0.61 & 0.63 & -0.48 & 0.26 & 0.42 & -0.61 & 0.29 & 0.21 & -0.52 & 0.48 \\
\hline U.S.A. & -0.84 & 0.83 & -0.22 & 0.46 & 0.55 & -0.43 & 0.59 & -0.03 & -0.12 & 0.87 \\
\hline
\end{tabular}




\section{Panel B: Significant Differences in Correlation of Political Risk}

$\begin{array}{ccccccccccc}\text { Ztest } & \text { Bahrain } & \text { Egypt } & \text { Israel } & \text { Jordan } & \text { Lebanon } & \text { Morocco } & \text { Oman } & \text { Saudi Arabia } & \text { Turkey } & \text { Tunisia } \\ \text { Japan } & \mathbf{4 . 8 1} & \mathbf{1 . 5 7} & 1.29 & \mathbf{2 . 2 1} & -0.56 & \mathbf{4 . 1 7} & 0.74 & 1.06 & \mathbf{- 2 . 0 4} & \mathbf{- 2 . 2 1} \\ \text { U.K. } & 0.62 & \mathbf{2 . 0 4} & 1.10 & \mathbf{3 . 4 1} & \mathbf{5 . 0 4} & \mathbf{- 6 . 1 4} & \mathbf{- 2 . 9 5} & 0.64 & 1.09 & \mathbf{- 1 . 8 7} \\ \text { U.SA. } & -0.72 & \mathbf{4 . 0 7} & \mathbf{3 . 1 0} & \mathbf{5 . 8 8} & \mathbf{5 . 8 0} & \mathbf{- 3 . 9 5} & -1.11 & \mathbf{1 . 7 8} & \mathbf{2 . 2 5} & \mathbf{2 . 0 8}\end{array}$

\section{Summary and Conclusion}

In this study, we highlighted the major structural changes and developments that occurred in the MENA capital markets during the last decade. High growth was observed in market capitalization, number of listed companies, value traded and shares traded in most of the MENA capital markets over the period of this study. Stock market boom was also observed in many of the MENA countries. Most stock markets in the region have seen heavy investments which have pushed the key indices to very high levels by the end of 2005. Among the reasons that were given for the high performance in the MENA stock market is the increased liquidity and improved economic fundamentals in the region due to high oil prices and the reluctance of rich Arab investors to invest in overseas markets after the events of September 11, 2001; instead, they invested in local markets. The boom was followed by a major correction (crash) in some of the MENA countries. Some of these markets such as the Saudi market gave away most of the gains it accumulated in the fouryear rally that preceded the stock market crash.

We also tested in this study the notion that MENA market country equities are considered as a similar asset class to developed country equities. The results of the study partially support the evidence of higher emerging market returns compared to the developed countries that has been documented in a number of studies. High returns were recorded only for some of the countries in the MENA region during the whole period of study. During the first sub period (1995-1999), there was a major increase in the risk level for most of the 
MENA countries. As a result, the risk-adjusted return for all of the MENA countries (except Saudi Arabia) dropped below the risk-adjusted return for the U.K., the U.S.A., and the world. During the second sub period (2000-2004), a major shift in the relative performance of developed countries and MENA countries occurred. Five of the MENA countries had high positive returns and outperformed the developed countries. The tragedy of September 11 may have had a distorting impact on returns and risks of the developed countries.

The correlation tests in this study show that capital market integration has accelerated in recent years both economically and politically, but only for two to three countries in the MENA region. Therefore we conclude that the MENA market countries should continue to be viewed as separate asset class from developed countries. These markets seem to be highly segmented and provide great diversification potentials to global investors. It is clear that a number of frictions and barriers still restrict MENA markets from being fully integrated, especially in the areas of legal enforcement and accounting standards. However, the steps towards liberalization of MENA capital markets, their increased openness and new developments in information and other technologies will have a positive impact on the degree of integration with other world capital markets in the future. 


\section{References}

Bekaert, G., C. Harvey, and R.L. Lumsdaine. (2002) "Dating the integration of world equity markets." Journal of Financial Economics 65 (20): 203-247.

DeSantis, G., and S. Imrohorglu. (1997) Stock returns and volatility in emerging financial markets.” Journal of International Money and Finance 16, 561-579.

Harvey, C. (1995a) "The cross-section of volatility and autocorrelation in emerging markets," Finanzmarkt und Portfolio Management 9, 12-34.

Henry, P.B. (2000) "Stock market liberalization, economic reform and emerging market equity prices," Journal of Finance 55, 529-546.

Liew, J. (1995) "Stock returns, inflation and the volatility of growth in the money supply: Evidence from emerging markets,” m University of Chicago, Working Paper Series.

Mei, J. "Political risk, financial crisis and market volatility." Working paper, Stern School, New York University, 1999.

Saunders, A. and I. Walter (2002) “Are emerging market equities a separate asset class?” Journal of Portfolio Management 28 (3), 102-115.

Tahsin, S. and M. Petri (2006) “The Jordanian stock market - should you invest in it for risk diversification or performance?” IMF working paper series, no. 06/187 (August) 